\title{
Greek and Latin Love
}





\section{Greek and Latin Love}

The Poetic Connection

Edited by

Thea S. Thorsen, Iris Brecke, and Stephen Harrison 
ISBN 978-3-11-063059-6

e-ISBN (PDF) 978-3-11-063303-0

e-ISBN (EPUB) 978-3-11-063061-9

Library of Congress Control Number: 2021939452

Bibliographic information published by the Deutsche Nationalbibliothek

The Deutsche Nationalbibliothek lists this publication in the Deutsche Nationalbibliografie; detailed bibliographic data are available on the Internet at http://dnb.dnb.de.

(C) 2021 Walter de Gruyter GmbH, Berlin/Boston

Cover Image: Cupids playing with a lyre. Roman fresco from Herculaneum (detail) @ The Picture Art Collection / Alamy Stock Foto

Printing and binding: $\mathrm{CPI}$ books $\mathrm{GmbH}$, Leck

www.degruyter.com 